\title{
The Exegesis Tradition of Song of Songs and Richard Crashaw's Baroque Poem
}

\author{
Yi Zheng ${ }^{1}$ \\ ${ }^{1}$ College of International Studies, Southwest University, Chongqing, China; School of Linguistics and Literature, \\ University of Electronic Science and Technology of China, Chengdu, China \\ Correspondence: Yi Zheng, School of Linguistics and Literature, University of Electronic Science and \\ Technology of China, No. 2006, Xiyuan Ave, West Hi-Tech Zone, 611731, Chengdu, Sichuan, China. Tel: \\ 86-136-8848-3836. E-mail: zhengyismile@aliyun.com
}

Received: July 10, 2015 Accepted: July 28, 2015 Online Published: August 31, 2015

doi:10.5539/ells.v5n3p113 URL: http://dx.doi.org/10.5539/ells.v5n3p113

\begin{abstract}
The exegesis tradition of the Song of Songs usually defines the bride and bridegroom of this poem as the church and Christ. So their marriage refers to the mystical union between the individual soul and the Word of God. Richard Crashaw's famous Baroque poem "The Flaming Heart" illustrates the expectation and desire that Saint Teresa of Avila has towards her divine spouse. It also describes the raptures that the saint experiences after she has mystical union with God. To Crashaw, St. Teresa's love to God is very similar to the love between the bride and bridegroom in the Song of Songs. By showing her ardent love, our love towards God has been kindled.
\end{abstract}

Keywords: Richard Crashaw, the exegesis tradition, Baroque poem

\section{Introduction}

Richard Crashaw is a religious poet of the 17th century England. In his brief career, he writes to pay piety to the Father and the Son with all his heart, his soul and strength. He also writes to show homage to the saints, among whom the $16^{\text {th }}$ century Spanish Saint Teresa of Avila has become a profoundly inspirational experience to him. She evidently becomes for him the perfect symbol of the Christian humility necessary to achieve a spiritual union with God (Klemans, 1971, p. 154). To Crashaw, St. Teresa's love to God is very similar to the love between the bride and bridegroom in Song of Songs.

Living in the age of Baroque period, Crashaw's poetry is imbued with strong Braque style. Thus Crashaw is generally recognized as a famous and achieved Baroque poet of the $17^{\text {th }}$ century. T. S. Eliot thinks that Crashaw "as the representative of the baroque spirit in literature" (Eliot, 1929, p. 125). Douglas Bush also points out that "Crashaw is the one conspicuous English incarnation of the "baroque sensibility" (Bush, 1962, p. 147).

Long in the literary history, Crashaw has not been paid due attention and respect for he was a Catholic and the so-called "bad taste of his poetry" (Klemans, 1971, p. 166). So far, Crashaw's Baroque poem"The Flaming Heart" has been read from the following aspects. Austin Warren has analyzed the emotional ups and downs that both the saint and the poet have experienced; Patricia A. Klemans has discussed in detail the "fire" image; Louis L. Martz has explained the Baroque elements in the conclusion parts of this poem. Mario Praz has compared the image of its ending part to some other poets' works. However, there has not been research about it from the perspective of the exegesis tradition of the Song of Songs. Therefore, this paper tries to read it from this aspect to give some new light to the reading of Crashaw's poetry.

\section{The Exegesis Tradition of the Song of Songs}

The Song of Songs is the most complex, most widely interpreted book in The Old Testament, as David Stern puts it: "No biblical book's ancient interpretation is more extensively documented than that of the Song of Songs. Nor is there another biblical book that has so clearly been subjected to so many different exegetical approaches" (Stern, 2008, p. 87). Up to now, there has been no consensus as to who is the author of this poem. It is said that the son of David, Solomon writes it. Solomon writes it in the form of a drama and it is sang under the figure of the bride, about to wed and burning with heavenly love towards her bridegroom (Origenes, 1957, p. 21). So as complex is the content of the Scripture. There is no direct mention of God. Instead, from a literal sense, readers can easily find that this book celebrates the passionate joys of two lovers: Solomon and the Shulammite fall in 
love with each other and finally get married. In demonstrating their love story, there are quite a lot of sensual descriptions, such as 1.4, 3.4, 4.5-6 and 7.7-9. So the carnally minded readers who approach it have been wondering why this book with so many erotic details has become canonized both within the Hebrew Bible and the Christian Bible. What does it talk about indeed?

This question starts the allegorical reading tradition of the book. As a canon in the Armaic Targum, the Jewish theologians make many and different interpretations to it. At the earliest time, they believe that this book writes about the sweet sexual relationship between couples: God creates men and gives them the right to enjoy physical pleasure. Later, the Neo-Platonism arises and it holds that the corporeal desire is vulgar and should be forbidden (Zhao, 1994, p. 41). Such ascetic idea leads to the allegorical reading of the book. Generally speaking, the Synagogue scholars identify the bride with Yahweh's chosen people Israel. So the true subject of the poem is the mutual expression of love between them (Stern, 2008, p. 89). Therefore, for example, 1.4 of the song "The king has brought me into his chambers" does not have any sexual implications. Rather, it means that God leads the Israel out of Egypt to the Promised Land "flowing with milk and honey".

The Christian exegesis of the song starts from Hippolutus of Rome. He was the first father of early church to interpret the book in a spiritual way. He defines the intimate bridegroom and bride relationship as Christ and His church. So, 1:4 is explained as Christ brings his beloved disciples into the church. Another scholar Origenes Adamantius furthered this opinion and systematizes the allegorical reading of this book. He holds that the two in the Song was the Divine-Human nature of the Logos. So he explains the Song actually refers to the mystical union between the church and Christ or the individual soul and the Word (Origenes, 1957, pp. 6-50). Origen's identification of the Bride with the church or soul has remained the basis for all subsequent interpretation of the Song's veiled meaning (Astell, 1990, p. 4). Those medieval scholars such as Anselm of Laon, Bruno of Segni, Bernard of Clairvaux all hold the same idea. Although 1517 witnessed the starting of religious reform and people have been arguing who is the real bride of Christ, Catholics or Christians. But all in all, bride is Christ's faithful disciples.

The Christian exegesis of the husband-wife relationship in the book shows the intimacy between Christ and his disciples can be seen from two aspects. First is the love that the Christians have towards God. Their love for Him make them be willing to contribute the best to Him, as the bride sings: "let us go out early to the vineyards, and see whether the vines have budded, whether the grape blossoms have opened and the pomegranates are in bloom. There I will give you my love. The mandrakes give forth fragrance, and over our doors are all choice fruits, new as well as old, which I have laid up for you, O my beloved (7:12-13)". Besides, their love is mixed with the desire and anxiety to be saved from the earth and going into heaven by Him. Through the whole song, we can easily find that the majority part of the song is sung by the woman, which shows that she expects him very much. Her expectation is so fierce that she sings: "Tell me, you whom my soul loves, where you pasture your flock, where you make it lie down at noon (1:7)". The most typical passages are 3:1-3 and 5:6-7. The two parts are very similar: deep at night, when the bride lies on bed, her man suddenly disappears. So she walked through the city to look for him. She feels quite anxious when she doesn't find him. Richard of S. Victor thinks that "city" in the passage implies the church, while "streets" and "squares" imply God's followers. The woman rushes into the city to seek for the man indicates that she is looking for the way to be saved by God (Littledale, 1869, p. 113). She has finally moved her Master so he finally comes and she "held him, and would not let him go until I brought him into my mother's house (3:4)". On the other hand, God also loves his people. First, he leads them go into the church, to give them the chance to be saved: "Come with me from Lebanon, my bride; come with me from Lebanon. Depart from the peak of Amana, from the peak of Senir and Hermon, from the dens of lions, from the mountains of leopards (4:8)". Lebanon, Amana, Senir and Hermon are in the northern parts of Palestine, which are barren and haunted by wild animals. The man asks the woman to leave with him from these places symbolize the protection he gives them. He does not only lead his people out of danger, but also "brought me to the banqueting house, and his intention toward me was love (2:3)". Origenes thinks that those delicious dishes on the banquet are God's sayings and teachings (Origenes, 1957, pp. 186-187). Secondly, God's love has been to such an extent that he knows them very clear. The poem describes the man has such an intimate relationship with the woman that maybe they already have had sexual intercourse, as the man declares in 7.7-9: "You are stately as a palm tree, and your breasts are like its clusters. I say I will climb the palm tree and lay hold of its branches. Oh, may your breasts be like clusters of the vine, and the scent of your breath like apples, and your kisses like the best wine." The Shulammite's fleshly breasts, chanting figure and sweet mouth are very inviting and attractive to the man. According to the Christian exegesis, they show that God knows his believers very much.

All in all, the whole song depicts a picture of mutual longing and desire that the man and the woman express for each other. Their sexual union in this book has been seen to have archetypal function as to foreshadow the 
mystical marriage with God in English literature. As a religious poet and a pious follower of God, such feelings are reflected in Richard Crashaw's poem "The Flaming Heart".

\section{The Soul's Mystical Union with Christ in "The Flaming Heart"}

"The Flaming Heart" is generally regarded as the best poem written by Crashaw, who composed it after he had read the inspirational life story of the $16^{\text {th }}$ century Spanish Saint Teresa of Avila: "I would see beside me, on my left hand, an angle in bodily form...In his hands I saw a long golden spear and at the end of the iron tip I seemed to see a point of fire. With this he seemed to piece my heart several times so that it penetrated to my entrails. When he drew it out, I thought he was drawing them out with it and he left me completely afire with a great love for God (Teresa, 2004, p. 244)." Another saying is that Crashaw writes this poem based on Antwerp artist Gerhard Seghers' painting (Martz, 1991, p. 201), because the title of the poem is "THE FLAMING HEART UPON THE BOOK AND Picture of the seraphicall saint TERESA, (AS SHE IS USUALLY EXPRESSED with a SERAPHIM beside her.) (Crashaw, 1970, p. 62)". Crashaw learns the ardent love of this saint and describes her as Shulammite in the Song who is thirsting for her heavenly espouse God and after she experiences both physical and spiritual consummation with Him, she enters a state ecstasy. And by the power of his poem readers burn the love for the Divinity.

This poem firstly dwells at length on pointing out the mistakes in Seghers' painting. Carshaw thinks that Seghers has mistaken Teresa's transverberation described in her autobiography Vida, for he portrays her as a weak, pale, almost faintly lady who has bright cheeks only because of that bright Book besides her.

Had thy cold Pencil kist her PEN

Thou couldst not so unkindly err

To show us This faint shade for HER.

Why man, this speakes pure mortall frame;

And mocks with female FROST love's manly flame.

One could suspect thou meant'st to paint

Some weak, inferiour, woman saint.

But had thy pale-fac't purple took

Fire from the burning cheeks of that bright Booke (Crashaw, 1970, p. 63)

However, the truth is that deep in the saint's heart, she has burned out "mistresse flame" for her Master. The flame is so blooming that it even attracts the Seraphim to descend from the heaven to watch it:

This is the mistresse flame; and duteous he

Her happy fire-works, here, comes down to see. (Crashaw, 1970, p. 63)

The word here "mistresse" clearly shows that the love is not only the worship that a pious disciple has towards God, but also it refers to sensory pleasure. As Teresa is often thought as a mystic who falls into trances, sees visions, and possesses powers of levitation (Klemans, 1971, p. 153), we may infer that it is very natural that she has cast all her sexual desire to the man who she admires most. Normally, desire is often understood only as pure sexual impulse which makes Christians feel disgusting and thus condemn it. However, desire can also be viewed as a way for Christians to access to God. Teresa's "mistresse flame" is so fierce that it makes her heart flame. This flaming heart changes her from an ordinary-looking woman into a radiant, beautiful lady, into the one who has "rosy fingers, radiant hair, glowing cheeks (Crashaw, 1970, p. 63)". At this moment, she looks very much like any woman who meets her love and has both soul and physical communication with him. Her radiance does not only change herself, but also change the angle beside her, who also becomes brilliant because of the love fire. So, readers have to, as Austin Warren says, "to reverse the picture, and reverse the sexes of the participants; for Teresa was 'for masculine courage of performance more than a woman' (Warren, 1957, p. 141)":

Since His the blushes be, and her's the fires,

Resume and rectify thy rude design;

Undresse thy Seraphim into MINE.

Redeem this injury of thy art;

Give HIM the vail, give her the dart. (Crashaw, 1970, p. 63)

Another word "fire" here indicates that God has responded to her love. God comes to her as Solomon in the Song: 
"Arise, my love, my fair one, and come away (2:10)". Solomon marries Shulammite with a litter, while the Divinity marries the saint with the fire. Fire is the token that she has been with God, because according to the traditional western cosmos, the upward elements of the universe are soil, water, air and fire. The space where fire is in is far away from the earth and comes very close to the heaven where God is in. Thus, the burning fire shows very clearly that the saint's soul has mystical union with God. Crashaw holds that the saint is in such an ecstatic condition that she pierces us with her dart of love: "the Hand of this great HEART (Crashaw, 1970, p.63)". Here, the poet uses a Baroque conceit. Baroque conceit is a striking word picture or image that Baroque poet often uses in poetry (Segel, 1974, 102). Her love is so strong and ardent that she arouses emotive response from the poet. And the poet in the same way passes the feelings into the reader's relationship with God:

$\mathrm{O}$ thou undanted daughter of desires!

By all thy dowr of LIGHTS and FIRES;

By all the eagle in thee, all the dove;

By all thy lives and deaths of love;

By thy larg drauhts of intellectuall day,

And by thy thirsts of love more large then they'

By all thy brim-fill'd Bowles of fierce desire

By thy last Morning's draught of liquid fire;

By the full kingdome of that finall kisse

That seiz'd thy parting Soul, and seal'd thee his;

By all the heav'ns thou hast in him

(Fair sister of the SERAPHIM!)

By all of HIM we have in THEE; (Crashaw, 1970, p. 65)

These are the last 16 lines of the poem, which sound very much like a church litany. Here, not only the saint has experienced mystical union with God, but also the poet and readers have enjoyed a willing, loving and happy surrender to his will. Martz comments that in content, this is a traditional ending of a formal meditation, a colloquy with the saint, asking for her aid in the redemption of the speaker's self. In technique, here Crashaw uses a characteristic baroque repetition, i.e., using the same images and phrases in a new passage. The image upon image here serves to give us a strong sensory impression and help to express the poet feelings (Martz, 1991, pp. 204-205). So, by choosing the example of a canonized saint to illustrate the love between God and man, Crashaw kindles our love for God.

\section{Conclusion}

As a Baroque poet of the $17^{\text {th }}$ century England, Crashaw imbued his poem with strong Baroque elements. Meanwhile, he tries to express his ardent and pious love to the divinity in this poem "The Flaming Heart" through the saint. The religious emotions demonstrated in this poem is quite similar to the feelings showed in the Song. And the saint is the bride who desires for the coming of her Master. Or we should say, in describing the saint's longing for God, the poet actually expresses his own love for the Divinity: he is longing for, and he is looking for his love and finally gets it. The love is so intense and ardent that we readers have been deeply touched by it after we read this poem.

\section{References}

Astell, A. W. (1990). The Song of Songs in the Middle Ages. New York: Cornell University Press.

Bush, D. (1962). English literature in the earlier seventeenth century, 1600-1660 (2nd ed.). Oxford: Oxford University Press.

Crashaw, R. (1970). The complete poetry of Richard Crashaw (George Walton Williams, Ed.). New York: Doubleday \& Company, Inc.

Eliot, T. S. (1929). For Lancelot Andrewes. London: Faber \& Gwyer Limited.

Klemans, P. A. (1971). Richard Crashaw: England’s Baroque Poet. Michigan: University Microfilms, A Xerox Comapny.

Littledale, R. F. (1869). A Commentary on the Song of Songs from Ancient and Medieval Sources. New York: Pott and Amery. 
Martz, L. L. (1962). The poetry of meditation. London: Yale University Press.

Origenes. (1956). The Song of Songs Commentary and Homilies. London: The Newman Press,

Segel, H. B. (1974). The Baroque poem. New York: E.P. Dutton \& Co., Inc.

Stern, D., \& Dohrmann, N. B. (2008). Jewish Biblical Interpretation and Cultural Exchange. Philadelphia: University of Pennsylvania Press.

Teresa of Avila. (2004). The life of Teresa of Jesus. (E. Allison Peers, Ed.). New York: Doubleday.

Warren, A. (1957). Richard Crashaw: A study in baroque sensibility. Michigan: The University of Michigan Press.

Zhao, D. (1994). The 1500 Years Christian Philosophy. Beijing: Remin Publishing Press.

\section{Copyrights}

Copyright for this article is retained by the author(s), with first publication rights granted to the journal.

This is an open-access article distributed under the terms and conditions of the Creative Commons Attribution license (http://creativecommons.org/licenses/by/3.0/). 